\title{
PROBLEMS OF STATISTICAL STUDY OF "GREEN ECONOMICS" AND GREEN GROWTH POTENTIALS IN THE SUSTAINABLE DEVELOPMENT CONTEXT
}

\author{
Tetyana Melnyk ${ }^{1}$, Nataliia Reznikova ${ }^{2}$, Oksana Ivashchenko ${ }^{3}$
}

\begin{abstract}
The purpose of the research. The research subject purpose is theoretical and practical aspects of the statistical assessment of the green economy potential in the sustainable development context. The methods. The article is based on the categories of theoretical (hypothesis, concept, theory, problem) and empirical (facts, empirical summarizations, empirical dependences) level of the issue, distinctive features of which are: objectivity; categorical character; rationality; testability; high level of generalization; universality and use of special tools and methods of cognition. General scientific and special methods of research are used to achieve the article's purpose and solve its problems, namely: methods of analysis, abstraction and synthesis, induction and deduction, and system structuring method; hypothetico-deductive method; method of historical and logical integrity; method of idealization; methods of classification and system generalization; statistical methods. Considering that further "greening" of socio-economic indicators constitutes a vital problem remaining on the agenda of global and national institutes of development, the article's objective is to develop an integral approach to the revision of the System of Environmental-Economic Accounting (SEEA) built by the UN approach, through comparing existing approaches to the statistical assessment of the green economy state and the green growth potential, taking into account the proposed energy indices and indicators. Results. It is demonstrated that because none of the integral indicators of "green economy" development has been widely adopted by now, national and international statistics have no grounds for separating green goods and services as a specific sector of the national economy. Practical implications. The System of EnvironmentalEconomic Accounting (SEEA) has been adopted as a basic tool for the assessment of indicators reflecting the causal links between the economy and the environment. It is substantiated that most part of the data for measuring green growth processes has to be possibly collected by SEEA. Value/originality. The importance of the assessment of the dynamics of national economy greening is demonstrated, because this type of analysis enables one to assess the change in the environmental impact of the new economic model by analyzing the factors and identifying most effective methods for decreasing environmental pressures of economic activities. The advantage of such assessment is that it can be made on the basis of the available statistical data. Considering that energy indices and indicators are widely used in many international reporting systems to assess the state of green economy and the potential of green growth in the sustainable development context, we made an attempt to systematize all the indicators by the two main groups: direct and indirect. It is revealed that international organizations (OECP, UNEP and the World Bank) attempt to unify the existing approaches in constructing their own algorithms for the assessment of "green growth", in particular with the indicators of Sustainable Development Goals. At the same time, national statistical agencies attempt to build a set of statistical indicators for the assessment of green economy development as indicators of demand for green products. It is demonstrated that harmonized definitions of economic activities concerned with the green industry and green jobs and comparable key indicators, if used internationally, will enable for the statistical assessment of the green economic development in space and time.
\end{abstract}

Key words: green economics, green growth, sustainable development, key indicators, system of environmentaleconomic accounting.

JEL Classifications: A12, B49, C18, O10

\footnotetext{
Corresponding author:

${ }^{1}$ Kyiv National University of Trade and Economics, Ukraine.

E-mail: melnikknteu998@gmail.com

${ }^{2}$ Institute of International Relations of Taras Shevchenko National University of Kyiv, Ukraine.

E-mail: reznikovanataliia@gmail.com

${ }^{3}$ National Academy of Statistics, Accounting and Audit, Ukraine.

E-mail: oi.nasoa@gmail.com
} 


\section{Introduction}

Issues of "green growth" to some extent overlap the notion of sustainable development. The notion of sustainable development is clearly defined and, importantly, has the methodological framework elaborated by the UN. Besides that, the sustainable development framework offers indicators defined worldwide, known to us from the definition of Sustainable Development Goals. The methodology of "green growth" is, to a large extent, scattered and can be traced in several approaches of international organizations such as OECD, UNEP and the Word Bank.

The definition of green economy is essentially close to one of the sustainable development. At the same time, the concept of green growth offers the way to achieve the sustainable development through the effective use of natural resources in economic activities. The policy of green economy is pursued in two key dimensions: "greening" of economic growth and seeking for the potentials resulting from the implementation of green economy principles.

The definitions of the notions "green economics" and "green growth", proposed by various international organizations, show lack of coherence in the approaches to their interpretation. Green economics is primarily about "use-value", not "exchange-value" or money. It is about quality, not quantity; it is about regeneration of individuals, communities and ecosystems, not about accumulation of either money or material (Milani, 2005). The Green Economics Institute is the world's leading think tank and development incubator for Green Economics and the Green Economy (Green Economics Institute, 2018). It examined the roots of Green Economics, which are extremely eclectic and diverse. Ecological economics recognize the interdependencies of the economic, social and ecological spheres, with the market being brought in only after equity and sustainability considerations are met, and only as a facilitator of the efficient allocation of resources (Kennet, Heinemann, 2006). According to the UNEP approach, Green Economy is a clean, environmentally friendly economy that promotes health, wealth, and well-being (UNEP, 2012), or is one that results in improved human well-being and social equity, while significantly reducing environmental risks and ecological scarcities (EEA, 2016).

According to the OECD methodology, green growth is not a replacement for sustainable development. It rather provides a practical and flexible approach for achieving concise, measurable progress across its economic and environmental pillars, while taking full account of the social consequences of greening the growth dynamic of economies. The focus of green growth strategies is ensuring that natural assets can deliver their full economic potential on a sustainable basis. That potential includes the provision of critical life support services, i.e., clean air and water, and the resilient biodiversity needed to support food production and human health. Natural assets are not infinitely substitutable and green growth policies take this into account (OECD, 2018). However, OECD experts clarify that Green Growth means fostering economic growth and development, while ensuring that natural assets continue to provide the resources and environmental services on which our well-being relies (OECD, 2018). The World Bank, as one of the influential institutes, defines green growth as the growth that is efficient in its use of natural resources, clean in that it minimizes pollution and environmental impacts, and resilient in that it accounts for natural hazards and the role of environmental management and natural capital in preventing physical disasters (Bowen, 2012).

The green growth approach adopted by the Ministerial declaration (the Seoul Initiative Network on Green Growth) and a regional implementation plan for sustainable development sought to harmonize economic growth with environmental sustainability, while improving the eco-efficiency of economic growth and enhancing the synergies between environment and economy. As with green economy, green growth attracted significant attention as a way out of today's economic doldrums in the aftermath of the 2008 financial crisis (SDGs, 2013). According to the approach of the Economic and Social Commission for Asia and the Pacific (ESCAP), green growth, or environmentally sustainable economic growth, is a strategy of sustaining economic growth and job creation necessary to reduce poverty in the face of worsening resource constraints and climate crisis (ESCAP, 2012). Summing up the above given interpretations of "green economics" and "green growth", we are going to propose our definition: green economics is the economics leading to the increased welfare of people and the assured social justice along with the reduced environmental risks due to the sustainable economic growth, which includes elaboration of political decisions on the implementation of energy-saving technologies and "clean production" methods. The indicators for green economics assessment need to meet the overall criteria applied to statistical indicators, to make the data comparable in time and space and conforming to OECD criteria, so that they could be used in the policy making process. It means that the statistical indicators need to be authentic, measurable, comparable, politically relevant, acceptable in terms of costs for collection, processing and dissemination of information, and useful in communications (comprehensible both for target users and broader public). Some of the indicators proposed by international organizations cannot be computed today due to high costs for statistical data collection and processing. Finding of necessary directions for the statistical information development can act as a stimulus for improving data collection and processing. 
The assessment of developments in green economics, trade in green products and creation of green jobs is an important part of the green economics studies. In spite of broad discussions of these issues in the research community, a single definition of the categories of green industry and green jobs has not existed by now. The first work on issues of the assessment of production of ecological goods and services was published by OECD in collaboration with Eurostat in 1999. The principles for defining green economics and the first set of data for some European countries were elaborated and released by Eurostat in 2010. But it is not sufficient for constructing a system for the assessment of the green economics development.

The dynamic assessment of ecological goods, services and technologies at company and sectoral level covers two aspects: the assessment of green business as a source of innovation and a source of economic capabilities for green growth. The indicators of nature protection activities in business sector reflect the potential of green economics as a source of innovation, whereas the indicators of employment in green economics assess its social potential.

It needs to be noted the "algorithms" of green growth assessment constructed by the above-mentioned organizations (OECP, UNEP and the Word Bank) are focused on the comparison of domestic indicators with international ones, in particular sustainable development indicators. We are going to elaborate on how the approaches to the definition of "green growth" are implemented by these organizations.

\section{Further "greening" of socio-economic development indicators: the importance of the problem}

Further "greening" of the socio-economic indicators is a vital objective remaining in the agenda of global and national institutes of development. National statistical agencies attempt to construct a set of statistical indicators for the assessment of green economics development as indicators of demand for green products.

International organizations such as UNEP (Green Economy Initiative), the UN Statistical Office, The United Nations Economic Commission for Europe (UNECE or ECE), OECD recommend to use the System of Environmental-Economic Accounting (SEEA) as the underlying instrument enabling to assess the indicators reflecting the causal link between economics and environment; a major part of the data for the measurement of the processes involved in green growth need to be collected as far as possible in conformity with SEEA (OECD, 2011).

As mentioned in the OECD Green Growth Studies, The SEEA Central Framework is a multi-purpose, statistical framework that describes the interactions between the economy and the environment, and changes in stocks of environmental assets. It uses concepts, definitions, classifications and accounting principles that are in line with those of the system of national accounts (SNA). This makes the SEEA a valuable tool for deriving indicators that monitor the interactions between the economy and the environment. By applying the SEEA

Table 1

Overview of selected indicator types and relevant SEEA accounts

\begin{tabular}{|l|l|l|}
\hline \multicolumn{1}{|c|}{ Topic or issue } & \multicolumn{1}{|c|}{ Indicator examples } & \multicolumn{1}{c|}{ Examples of relevant SEEA accounts } \\
\hline $\begin{array}{l}\text { Environmental } \\
\text { efficiency }\end{array}$ & $\begin{array}{l}\text { Pollutant emission or waste generation intensities and } \\
\text { productivity ratios, relating the generation of residuals } \\
\text { to economic output: } \\
\text { - Carbon productivity and air emission intensities } \\
\text { - Waste generation intensities } \\
\text { - Nutrient balance intensities }\end{array}$ & $\begin{array}{l}\text { - Physical flow accounts for water } \\
\text { - Physical flow accounts for materials: product flows, } \\
\text { air emissions (including greenhouse gases), pollutant } \\
\text { emissions to water }\end{array}$ \\
\hline Resource efficiency & $\begin{array}{l}\text { Resource use intensities and productivity ratios, } \\
\text { relating resource inputs to economic output: } \\
\text { - Energy productivity } \\
\text { - Material productivity } \\
\text { - Water productivity }\end{array}$ & $\begin{array}{l}\text { - Physical flow accounts for materials: solid waste } \\
\text { accounts, economy-wide material flow accounts } \\
\text { - Physical flow accounts for water } \\
\text { - Physical flow accounts for energy }\end{array}$ \\
\hline Natural assets & $\begin{array}{l}\text { - Intensity of use of natural resource stocks, relating } \\
\text { resource extraction to available stocks: water, minerals, } \\
\text { energy, timber, fish } \\
\text { - Index of natural resources } \\
- \text { Land use and cover changes } \\
\text { - Soil productivity }\end{array}$ & $\begin{array}{l}\text { Asset accounts for: } \\
\text { - Water resources } \\
\text { - Mineral and energy resources; Timber resources; } \\
\text { Aquatic resources } \\
\text { - Land and soil resources } \\
\text { SEEA experimental ecosystem accounts }\end{array}$ \\
\hline $\begin{array}{l}\text { Environmentally- } \\
\text { related activities and } \\
\text { instruments }\end{array}$ & $\begin{array}{l}\text { - Share of environmentally-related activities in the } \\
- \text { Level and composition of environmental expenditure } \\
\text { - Environment related tax rate and revenue structure } \\
- \text { Environment-related support measures, e.g. fossil fuel } \\
\text { subsidies }\end{array}$ & $\begin{array}{l}\text { - Environmental activity accounts and statistics: } \\
\text { environmental protection and resource management } \\
\text { expenditure, environmental goods and services } \\
\text { environment: payments, transfers }\end{array}$ \\
\hline
\end{tabular}

Sources: compiled by the authors 
framework, monetary and physical data can easily be combined in a consistent format, for example for calculating intensity and productivity ratios. And macrolevel, indicators can be broken down by economic sector and by industry, to show structural changes over time, to analyze environmental pressures exerted by different industries, and to distinguish government responses from those of the business sector or private households. This is important when the indicators address both the environmental effectiveness and the economic efficiency of policies, or when they are to support structural policy analyses (OECD, 2015). It is the new SEEA system that enables to proceed to the computation of new global indicators, which, with exception of the capital produced by human labor, account for the nature capital, its depletion and effects for the environmental quality. Apart from non-renewable resources, the nature capital includes renewable resources (such as forests) and ecological services (OECD, 2014).

The distinction of "green" accounts from the traditional economic indicators is caused mainly by two estimates: the cost estimate of the depletion of natural resources and the environmental-economic damage from pollution. As the whole set of indicators is subject to permanent methodological refinement, the indicators' titles and computation methods can often be changed, thus complicating their use for correct crosscountry assessments and comparisons.

The elaborated framework for the statistical assessment of "green economics" has special importance in setting up the directions for the statistical reporting development in SEEA. In view of the requirement of data comparability in time and space, the method for computation of indicators needs to be harmonized internationally. There are various international databases enabling to cohere parts of the overall picture, such as database of the International Energy Agency (IEA), FAO Statistical Program of Work on Land Use, Water Use and Agricultural Production, and the database of the United Nations Framework Convention on Climate Change, UNFCCC. At the same time, there are statistical databases constructed by various research teams, which may often be without official status but can be used in indicative planning. There still remain many unsolved problems related with valuating nature assets and ecological services, which raises the importance of the problem of the comprehensive assessment of green economy.

Eurostat computes a group of indicators entitled "Sustainable Development Indicators" on the basis of 17 Sustainable Development Goals (SDGs, 2018). Goal 7 "Ensure Access to Affordable, Reliable, Sustainable and Modern Energy for All" covers 8 indicators: Primary energy consumption, Final energy consumption, Final energy consumption in households per capita, Energy productivity, Share of renewable energy in gross final energy consumption by sector, Energy dependence by product, Population unable to keep home adequately warm by poverty status, Greenhouse gas emissions inten- sity of energy consumption. The "Energy productivity" indicator is worth mentioning, which measures the output per unit of gross internal energy consumption. The gross internal energy consumption covers the consumption of primary energy plus energy carriers used for non-energy purposes (EUROSTAT, 2018).

Energy efficiency is an important issue for the EU. The primary importance of energy issues is caused by the EU intention to decrease energy expenditures and reduce the dependence from energy suppliers. The targets for 2020 and 2030 have been set to achieve this goal. $20 \%$ reduction of energy use is set till 2020, which is equivalent to the closure of 400 power plants. The goal set in 2016 is to achieve $30 \%$ reduction of energy use till the year of 2030. The European Commission prepares and releases the annual report with indicating the progress towards these goals (EC, 2018).

The biggest success is achieved by OECP of the abovementioned institutions (the World Bank, UNEP, OECP and Global Green Growth Institute). This organization has constructed its own system for the measurement of "green growth". The system covers main characteristics of "green growth", the underlying principles of reporting and the model of pressure-state-response (PSR). The indicators constructed by OECD can also be used for the analysis of Sustainable Development Goals, in particular Goal 6 "Ensure Access to Water and Sanitation for All" and Goal 12 "Ensure Sustainable Consumption and Production Patterns".

As it is emphasized in Report "Towards Green Growth: Monitoring Progress: OECD Indicators", the main purpose of the conceptual framework is to organize thinking about indicators and to identify relevant, succinct and measurable statistics. The framework is not an alternative to international guidelines on which the underlying data series should be based, in particular the System of Integrated Environmental and Economic Accounting (SEEA). Rather the conceptual framework has to build on definitions and accounting conventions such as those provided by the SEEA. The SEEA is currently being revised. When finalized and implemented, many indicators described in the present document such as environmental productivity are best derived from the SEEA accounting framework (OECD, 2011).

Apart from this, OECP in collaboration with the European Environmental Agency, UNECE, UNEP, is working on the implementation of the Shared Environmental Information System (SEIS), in order to improve collection, exchange and dissemination of information about the environment in the PanEuropean region.

Summing it up, "green growth" indicators of OECD consist of the following four groups: 1) environmental and resource productivity; 2) the natural asset base; 3) environmental quality of life; 4) economic opportunities and policies.

25 to 30 indicators were set within these 4 directions (OECD, 2016). 
Vol. 6, No. 3, 2020

Table 2

\section{Indicator groups and topics covered}

\begin{tabular}{|c|c|c|}
\hline 1 & $\begin{array}{l}\text { The environmental and resource productivity of the } \\
\text { economy }\end{array}$ & $\begin{array}{l}\text { - Carbon and energy productivity } \\
\text { - Resource productivity: materials, nutrients, water } \\
\text { - Multi-factor productivity }\end{array}$ \\
\hline 2 & The natural asset base & $\begin{array}{l}\text { - Renewable stocks: water, forest, fish resources } \\
\text { - Non-renewable stocks: mineral resources } \\
\text { - Biodiversity and ecosystems }\end{array}$ \\
\hline 3 & The environmental dimension of quality of life & $\begin{array}{l}\text { - Environmental health and risks } \\
\text { - Environmental services and amenities }\end{array}$ \\
\hline 4 & Economic opportunities and policy responses & $\begin{array}{l}\text { - Technology and innovation } \\
\text { - Environmental goods \& services } \\
\text { - International financial flows } \\
\text { - Prices and transfers } \\
\text { - Skills and training } \\
\text { - Regulations and management approaches }\end{array}$ \\
\hline 5 & Socio-economic context and characteristics of growth & $\begin{array}{l}\text { - Economic growth and structure } \\
\text { - Productivity and trade } \\
\text { - Labour markets, education and income } \\
\text { - Socio-demographic patterns }\end{array}$ \\
\hline
\end{tabular}

Sources: compiled by the authors

23 priority indicators were set in 2011 (OECD, 2011).

Table 3

Overview of the proposed indicator groups and topics covered

\begin{tabular}{|c|c|c|}
\hline Main indicator groups & Topics covered & Related OECD work \\
\hline \multicolumn{3}{|c|}{ The socio-economic context and characteristics of growth } \\
\hline $\begin{array}{l}\text { Economic growth, productivity and } \\
\text { competitiveness }\end{array}$ & $\begin{array}{l}\text { Economic growth and structure } \\
\text { Productivity and trade } \\
\text { Inflation and commodity prices } \\
\text { Labour markets (employment / unemployment) } \\
\text { Socio-demographic patterns of income and } \\
\text { education }\end{array}$ & $\begin{array}{l}\text { Economic outlook, Economic surveys } \\
\text { Going for growth } \\
\text { National accounts, Productivity database } \\
\text { Employment outlook } \\
\text { Education at a glance } \\
\text { Health at a glance } \\
\text { Society at a glance }\end{array}$ \\
\hline \multicolumn{3}{|c|}{ Environmental and resource productivity } \\
\hline Carbon and energy productivity & $\begin{array}{l}\text { 1. } \mathrm{CO}_{2} \text { productivity (demand-based, production- } \\
\text { based) } \\
\text { 2. Energy productivity } \\
\text { 3. Material productivity (demand-based, } \\
\text { production-based) } \\
\text { Non-energy materials, waste materials, nutrients } \\
\text { 4. Water productivity } \\
\text { 5. Multi-factor productivity } \\
\text { reflecting environmental services }\end{array}$ & $\begin{array}{l}\text { IEA scoreboard } \\
\mathrm{CO}_{2} \text { emissions database } \\
\text { OECD input-output tables } \\
\text { Environmental indicators } \\
\text { Environmental reviews } \\
\text { Environmental outlook } \\
\text { Material flows \& resource productivity } \\
\text { Agri-environmental indicators } \\
\text { Productivity database }\end{array}$ \\
\hline \multicolumn{3}{|c|}{ Natural asset base } \\
\hline $\begin{array}{l}\text { Non-renewable stocks } \\
\text { Biodiversity and ecosystems }\end{array}$ & $\begin{array}{l}\text { 6. Freshwater resources } \\
\text { 7. Forest resources } \\
\text { 8. Fish resources } \\
\text { 9. Mineral resources } \\
\text { 10. Land resources } \\
\text { 11. Soil resources } \\
\text { 12. Wildlife resources }\end{array}$ & $\begin{array}{l}\text { Environmental indicators } \\
\text { Environmental reviews } \\
\text { Measuring progress } \\
\text { Material flows \& resource productivity } \\
\text { Environmental outlook } \\
\text { Agri-environmental indicators }\end{array}$ \\
\hline \multicolumn{3}{|c|}{ Environmental quality of life } \\
\hline Environmental services and amenities & $\begin{array}{l}\text { 13. Environmentally induced health problems } \\
\text { and related costs } \\
\text { 14. Exposure to natural or industrial risks and } \\
\text { related economic losses } \\
\text { 15. Access to sewage treatment and drinking water }\end{array}$ & $\begin{array}{l}\text { Measuring progress } \\
\text {-How's Life? } \\
\text { Environmental indicators } \\
\text { Environmental reviews } \\
\text { Environmental outlook } \\
\end{array}$ \\
\hline
\end{tabular}




\begin{tabular}{|c|c|c|}
\hline Main indicator groups & Topics covered & Related OECD work \\
\hline \multicolumn{3}{|c|}{ Economic opportunities and policy responses } \\
\hline $\begin{array}{l}\text { Technology and innovation } \\
\text { Environmental goods and services } \\
\text { International financial flows } \\
\text { Prices and transfers }\end{array}$ & $\begin{array}{l}\text { 16. R\&D of importance to GG } \\
\text { 17. Patents of importance to GG } \\
\text { 18. Environment related innovation } \\
\text { 19. Production of environmental goods and } \\
\text { services } \\
\text { 20. International financial flows of importance } \\
\text { to GG } \\
\text { 21. Environmentally related taxation } \\
\text { 22. Energy pricing } \\
\text { 23. Water pricing and cost recovery }\end{array}$ & $\begin{array}{l}\text { Innovation strategy } \\
\text { Science, technology \& industry } \\
\text { scoreboard } \\
\text { Patent database } \\
\text { R\&D database } \\
\text { Aid activity database } \\
\text { Database on environmental policy } \\
\text { instruments } \\
\text { Agri-environmental indicators }\end{array}$ \\
\hline $\begin{array}{l}\text { Regulations \& management approaches } \\
\text { Training \& skill development }\end{array}$ & Indicators to be developed & \\
\hline
\end{tabular}

Sources: compiled by the authors

The information base for the computation of these indicators is supposed to be too large and multidimensional. In its framework, OECD cooperates with other organizations and initiatives.

Table 4

\section{Relevant OECD work for monitoring progress towards green growth}

\begin{tabular}{|c|c|}
\hline \multicolumn{2}{|c|}{$\begin{array}{l}\text { The indicators needed to measure progress with green growth are founded on existing OECD work that is being refined to suit the Green } \\
\text { Growth Strategy. Continued co-operation is taking place with other international organizations, such as UNEP, the European Commission, } \\
\text { and international institutes }\end{array}$} \\
\hline $\begin{array}{l}\text { Measuring environmental } \\
\text { performance and resource } \\
\text { productivity }\end{array}$ & $\begin{array}{l}\text { The OECD has developed several sets of environmental indicators to support policy analysis and country } \\
\text { reviews: key and core environmental indicators to track environmental progress; sectoral environmental } \\
\text { indicators to monitor policy integration; and indicators to measure the decoupling of environmental } \\
\text { pressures from economic growth. The indicators are supplemented with environmental data, including on } \\
\text { environmentally related taxes and expenditure. Recent work has been focusing on the measurement of } \\
\text { material flows and resource productivity in support of an OECD Council recommendation and of the } \\
\text { G8 Kobe 3R Action Plan. }\end{array}$ \\
\hline $\begin{array}{l}\text { Monitoring trends in energy } \\
\text { use and efficiency }\end{array}$ & $\begin{array}{l}\text { The IEA maintains several databases, including energy balances, energy statistics, energy prices and taxes, } \\
\text { and publishes various types of energy indicators. Recent work has been focusing on the measurement of } \\
\text { energy efficiency in support of the G8 Gleneagles Plan of Action for Climate Change, Clean Energy and } \\
\text { Sustainable Development and on improving mandatory reporting of energy efficiency-related data. }\end{array}$ \\
\hline $\begin{array}{l}\text { Monitoring technology } \\
\text { developments and } \\
\text { innovation }\end{array}$ & $\begin{array}{l}\text { The OECD maintains several databases and indicator sets keeping track of developments in technology and } \\
\text { industrial performance: main science and technology indicators; indicators on the information economy, } \\
\text { globalization, and entrepreneurship; international patent database, input-output tables and estimates } \\
\text { of carbon embedded in trade. Recent work has been focusing on indicators in support of the OECD } \\
\text { Innovation Strategy, and on an indicator toolkit to promote and monitor sustainable manufacturing at } \\
\text { corporate level. }\end{array}$ \\
\hline $\begin{array}{l}\text { Measuring the environmental } \\
\text { performance of agriculture }\end{array}$ & $\begin{array}{l}\text { The economic and environmental performance of agriculture is monitored through a set of agri- } \\
\text { environmental indicators, supported with the measurement of agricultural producer support. }\end{array}$ \\
\hline $\begin{array}{l}\text { Monitoring international } \\
\text { transfers }\end{array}$ & $\begin{array}{l}\text { The OECD maintains two major databases monitoring international monetary transfers: international } \\
\text { investment flows and official development assistance. Recent work aims at developing indicators of } \\
\text { "green" foreign direct investment flows and at mapping relevant international investment flows by country } \\
\text { and sector of destination. }\end{array}$ \\
\hline $\begin{array}{l}\text { Measuring sustainable } \\
\text { development }\end{array}$ & $\begin{array}{l}\text { The OECD has been promoting the development of indicators and coherent approaches to measure } \\
\text { sustainable development. Recent work has been focusing on improving the measurement of different types } \\
\text { of capital with emphasis on human and social capital. }\end{array}$ \\
\hline $\begin{array}{l}\text { Measuring well-being and } \\
\text { progress }\end{array}$ & $\begin{array}{l}\text { The OECD promotes the development of better measures and indicators of people's well-being and } \\
\text { societal progress, to be used alongside standard economic measures such as GDP. Recent work aims at } \\
\text { implementing the recommendations of the Stiglitz - Sen - Fitoussi Commission with emphasis on well- } \\
\text { being and sustainability. }\end{array}$ \\
\hline Other relevant work & $\begin{array}{l}\text { To underpin its socio-economic analysis, the OECD further maintains databases on a wide range of other } \\
\text { topics that are important to characterize economic growth and its outcomes. Examples include: national } \\
\text { accounts, international trade, balance of payments, prices and taxes, productivity, government debt, } \\
\text { employment, education, health, etc. }\end{array}$ \\
\hline
\end{tabular}


Vol. 6, No. 3, 2020

Table 5

Overview of proposed headline indicators

\begin{tabular}{|c|c|}
\hline \multicolumn{2}{|c|}{ Environmental and resource productivity } \\
\hline Carbon productivity & 1. $\mathrm{CO}_{2}$ productivity \\
\hline Resource productivity & 2. Non-energy material productivity \\
\hline Multifactor productivity & 3. Multifactor productivity including environmental services \\
\hline \multicolumn{2}{|c|}{ The natural asset base } \\
\hline Renewable and non-renewable stocks & 4. Natural resource index \\
\hline Biodiversity and ecosystems & 5. Changes in land use and cover \\
\hline \multicolumn{2}{|c|}{ Environmental quality of life } \\
\hline Environmental health and risks & 6. Air pollution (population exposure to PM 2.5) \\
\hline \multicolumn{2}{|c|}{ Economic opportunities and policy responses } \\
\hline $\begin{array}{l}\text { Technology and innovation, environmental goods and services, } \\
\text { prices and transfers, etc. }\end{array}$ & Placeholder - no indicator specified \\
\hline
\end{tabular}

Sources: compiled by the authors

However, in the report "Green Growth Indicators 2014" (OECD, 2014), it was emphasized that once OECD attempts to derive and define a single indicator were abandoned, 6 headline indicators for "green growth" measurement were set. The number of indicators was reduced due to complications in the aggregation of data.

These 6 headline indicators need to meet 4 criteria:

1) cover economic and ecological dimensions;

Table 6

Indicators for issue identification

\begin{tabular}{|l|l|l|}
\hline UNEP cross-cutting thematic priorities & \multicolumn{1}{|c|}{ Possible issues of concern } & \multicolumn{1}{c|}{ Indicators } \\
\hline Climate change & $\begin{array}{l}\text { - Country contribution to anthropogenic } \\
\text { climate change } \\
\text { - Increased frequency/intensity of storm surges }\end{array}$ & $\begin{array}{l}\text { - Greenhouse gas emissions }\left(\mathrm{Kt}_{\text {of }} \mathrm{CO}_{2}\right. \\
\text { equivalent/year) } \\
\text { - Rainfall (mm/year) and evaporation } \\
\text { - Storm-related damages (USD/year) }\end{array}$ \\
\hline Ecosystem management & $\begin{array}{l}\text { - Deforestation } \\
\text { - Loss of critical ecosystem services }\end{array}$ & $\begin{array}{l}\text { - Forest cover (ha) } \\
\text { - Extent of land and marine conservation areas } \\
\text { (ha) }\end{array}$ \\
\hline Resource efficiency & $\begin{array}{l}\text { - Falling groundwater tables } \\
\text { - Low efficiency of nonrenewable energy sources }\end{array}$ & $\begin{array}{l}\text { - Water intensity or productivity (m3/USD) } \\
\text { - Coal consumption intensity (tonnes/GDP) }\end{array}$ \\
\hline Chemicals and waste management & $\begin{array}{l}\text { - Air pollution } \\
\text { - Soil contamination }\end{array}$ & $\begin{array}{l}\text { - Waste recycling and reuse (\%) } \\
\text { - Toxic heavy metal concentration, e.g., } \\
\text { Hg, Cd, Pb, Cr. (mg/kg) }\end{array}$ \\
\hline
\end{tabular}

Sources: compiled by the authors

Table 7

Indicators for policy formulation

\begin{tabular}{|l|l|}
\hline \multicolumn{1}{|c|}{ Police } & \multicolumn{1}{c|}{ Indicator } \\
\hline Green investment & $\begin{array}{l}\text { - R\&D investment (\% of GDP) } \\
\text { - EGSS investment (USD / year) }\end{array}$ \\
\hline Green fiscal reform & $\begin{array}{l}\text { - Fossil fuel, water and fishery subsidies (USD or \%) } \\
\text { - Renewable energy incentive (USD or \%) }\end{array}$ \\
\hline Pricing externalities and valuing ecosystem service & $\begin{array}{l}\text { - Carbon price (USD / ton) } \\
\text { - Value of ecosystem service (e.g. water provision) }\end{array}$ \\
\hline Green procurement & $\begin{array}{l}\text { - Expenditure in sustainable procurement (USD / year and \%) } \\
\text { - CO2 productivity of government operations (ton / USD) }\end{array}$ \\
\hline Green job skill training & $\begin{array}{l}\text { - Training expenditure (USD / year and \% of GDP) } \\
\text { - Number of people trained (person / year) }\end{array}$ \\
\hline
\end{tabular}

Sources: compiled by the authors 
Table 8

Indicators for policy assessment

\begin{tabular}{|l|l|}
\hline \multicolumn{1}{|c|}{ Well-being and equity } & \multicolumn{1}{c|}{ Indicators } \\
\hline Employment & $\begin{array}{l}\text { - Construction (person, \%) } \\
\text { - Gini coefficient }\end{array}$ \\
\hline Total wealth & $\begin{array}{l}\text { - Value of natural resource stocks (USD) } \\
- \text { Net annual value addition / removal (USD / year) }\end{array}$ \\
\hline Access to resources & $\begin{array}{l}\text { - Access to modern energy (\%) } \\
\text { - Access to sanitation (\%) }\end{array}$ \\
\hline Health & $\begin{array}{l}\text { - Level of harmful chemicals in drinking water (g / litre) } \\
\text { - Number of people hospitalized due to air pollution (person) }\end{array}$ \\
\hline
\end{tabular}

Sources: compiled by the authors

2014), containing references to some works of OECD, but not mentioning a cooperation on line of "green growth". Thus, UNEP relies upon the OECD logics when formulating the requirements to indicators.

UNEP methodology covers 4 aspects:

1) Issue Identification and Agenda Setting (indicators for issue identification are instruments that help decision makers identify and prioritize problems and set the agenda for policy interventions). Four spheres are defined in setting the problems with priority status for "green economics" with the respective indicators: 1) climate change; 2) ecosystem management; 3) reso-urce efficiency; 4) chemicals and waste management.

2) Policy formulation (indicators that allow to evaluate the adequacy of the interventions analyzed, taking into account their repercussions on the key actors in the economy and impacts across sectors).

3) Policy assessment (indicators that support the estimation and evaluation of policy impacts across sectors, with a more marked focus on indicators for socio-economic impacts and well-being).

4) Policy Monitoring and Evaluation (indicators for policy monitoring and evaluation support the assessment of the performance of the intervention implemented).

\section{Measurement of potential benefits from "green growth" policies}

In 2012, the World Bank released the report "Inclusive Green Growth". It is focused on the methodology for the measurement of potential benefits from "green growth" policies. Three types of benefits are defined: 1) environmental benefits; 2) economic benefits; 3) social benefits.

In spite of the above-mentioned approaches of three different organizations to constructing indicators of green economics and "green growth", all of them announced collaborative work to have the approaches harmonized.

Table 9

Framework for measuring potential benefits from green growth policies

\begin{tabular}{|c|c|c|}
\hline Type of benefit & Channels & Examples of indicators \\
\hline Environmental & Improved environment & $\begin{array}{l}\text { Indicators specifically developed for the domain in question (for } \\
\text { example, reduction in greenhouse gas emissions, natural area protected } \\
\text { from development, air or water quality) }\end{array}$ \\
\hline \multirow{3}{*}{ Economic } & $\begin{array}{l}\text { Increase in factors of production (physical } \\
\text { capital, human capital, and natural capital) }\end{array}$ & $\begin{array}{l}\text { Measured by the additional production from increased capital } \\
\text { (potentially measured by the value of ecosystems or renewable } \\
\text { resources), or by the value of additional capital }\end{array}$ \\
\hline & $\begin{array}{l}\text { Accelerated innovation, through correction } \\
\text { of market failures in knowledge }\end{array}$ & $\begin{array}{l}\text { Measured by productivity indicators (for example, efficiency of } \\
\text { photovoltaic panels used to produce electricity) or dissemination } \\
\text { indicators (for example, the fraction of the population with access to } \\
\text { photovoltaic electricity) }\end{array}$ \\
\hline & $\begin{array}{l}\text { Enhanced efficiency, through correction of } \\
\text { nonenvironmental market failures }\end{array}$ & $\begin{array}{l}\text { Measured by indicators for resource efficiency (for example, the material } \\
\text { or energy intensity of production, reduction in the value of time lost } \\
\text { from congestion), or by additional production }\end{array}$ \\
\hline \multirow{2}{*}{ Social } & $\begin{array}{l}\text { Increased resilience to natural disasters, } \\
\text { commodity price volatility, and economic } \\
\text { crises }\end{array}$ & $\begin{array}{l}\text { Measured by metrics related to the project, from avoided disaster } \\
\text { losses (in monetary terms) or number of people at risk from floods to a } \\
\text { measure of the vulnerability to oil price volatility }\end{array}$ \\
\hline & Job creation and poverty reduction & $\begin{array}{l}\text { Measured by the number of jobs created or an indicator of the impact on } \\
\text { the poor (for example, reduction in the number of people without access } \\
\text { to drinking water and sanitation) }\end{array}$ \\
\hline
\end{tabular}

Sources: compiled by the authors 
It was informed on the World Bank web-site in 2013 that the World Bank, UNEP, OECD and Global Green Growth Institute were working in collaboration on constructing indicators measuring "green growth" (the World Bank, 2013). It was noted that the following indicators were headline in the study of the progress of "green economics": the ecological and resource productivity and innovation; the nature assets (including biodiversity) and their management; the "ecological" quality of life (including the access to basic necessities such as clean water); relevant policies of "green growth", the economic capabilities and the social context of "green growth"; monitoring of sustainable development, overall economic development, by comprehensive measurement of welfare.

Thus, a section of OECD "Green Growth Indicators 2014" ("International Cooperation on Monitoring Progress Towards Green Growth") is devoted to the issue of OECD cooperation with other organizations in harmonization of the sustainable development methodology. Reference is also made on other publications and initiatives in this field. The partners involved include the United Nations Environment Program, the World Bank, the Global Green Growth Institute, the Green Growth Knowledge Platform, the Inclusive Wealth Report 2012, the Roadmap to a Resource Sufficient Europe, the European Commission's Grow Green assessment framework (UNEP, 2014).

\section{Analysis and discussion of results}

An extended model of economic growth needs to consider for the potential change in indicators of material welfare, such as net income accounting for change in nature assets. The indicator of net national income is intended for the assessment of material welfare of individuals and households. This indicator accounts for depreciation of fixed assets and intangible assets, and income flows between the country residents and the rest of the world. Another important indicator is real income of population, because it reflects the change in the conditions of trade, the dynamics of export prices compared with import ones.

The World Bank has performed a study on the measurement of wealth in combination with respective macroeconomic indicators. The indicator of adjusted net saving (ANS) is used by the World Bank to measure the sustainability of economic development. Measurement of adjusted net saving (ANS) is based on standard national accounting concepts. Adjusted net saving is obtained using the following identity:

Gross national saving - Consumption of fixed capital =Net national saving + Education expenditure-Energy depletion - Mineral depletion - Net forest depletion Damage from carbon dioxide emissions - Damage from particulate emissions $=$ Adjusted net saving .
Negative values of ANS signal that an existing social development model is non-sustainable. Its positive values can be a proxy of sustainable development due to the changed degree of interoperability of various forms of capital, resulting from science and technology advancement. Also, the World Bank gives the estimate of adjusted national income computed as the difference between the net national income and the use of natural resources, with pointing out that this indicator can be an estimate of "greening" of the economy (GGKP, 2013).

From the perspective of energy factor, the indicator of genuine savings is the most elaborated one with rather good international statistical database. The main components required for the computation of adjusted net savings (genuine savings) can be found in national account systems and the World Bank reports. All these components, namely, gross savings, consumption of fixed capital, education expenditures, depletion of energy resources, mineral depletion, net forest depletion, damage from carbon dioxide emissions, damage from particulate emissions, have the single computation methodology at global and country level. The computation of "genuine savings" indicators is performed by the World Bank for more than 100 countries, but the computations demonstrate a large gap between traditional economic indicators and ecologically adjusted ones. Negative values of ANA cannot be explained only by depletion of energy and mineral resources. The global practices show that advanced EU countries compensate the depletion of mineral resources by expenditures on education and $\mathrm{R} \& \mathrm{D}$. The structure of demand from business enterprises, households and government forms the structure of domestic and external supply and determines the overall structure economic growth in a country. There are many political instruments, such as taxes, subsidies or legal regulation, with effects for the consumer's behavior, changing the structure of demand. The scopes and structure of government consumption is an important factor of "greening" of the economy.

Therefore, the indicators describing a model of households' behavior and government consumption, such as consumption of organically pure products and relative prices for such goods, can be used as proxies of green economics trends. The main indicators that help in assessing the consumer behavior are the level of consumer awareness and education, the availability and quality of information about ecologically clean technologies. The weakness of these indicators is limited data for international comparisons.

A major part of ecological problems, such as climate change, the aggravated environmental performance or the reduced biodiversity, can be explained by the overlooking external environmental effects from economic activities in economic management. In order to have these effects included in the computation of production cost or in planning of 
new development strategies at company, regional or country level, researchers propose to give a definition to ecological services, i. e., the services rendered by the environment as a separate resource that can be depleted in case of its non-sustainable use. Two approaches to defining ecological services exist today. On the one hand, it can be said that a production facility, when polluting greenhouse gases, uses an ecological service, namely, the capability of the air to absorb greenhouse gases. On the other hand, these pollutions can be treated as a negative production output. The national accounts system includes ecological services related with use of land, mineral and energy resources, certain types of biological and water resources in case of a monetary benefit for their owner. Because change in the multifactor productivity is measured as the difference between change in the production output and change in the scopes of resources required for the output, an increase in unaccounted ecological services is reflected in computations as an increase in the multifactor productivity. It follows that the inclusion of key ecological services in an empirical analysis will help define the factors of economic growth and economic "greening" more accurately.

OECD defines the services that need to be included in the computation as ones with effects for the sustainable use of nature capital; it means that the indicator of carbon productivity of the production will be included in the set of indicators, because its dynamics is important for the assessment of the green economics development, whereas the indicator of use of solar energy per unit of production will not be included. The cost of ecological services can be estimated from the estimate of expenditures for reduction of the intensity of environmental pollution.

The inclusion of energy factors in the set of environmental-economic indicators is a rapidly expanding global tendency of sustainable development. Energy standards have been tightened drastically in developed countries in the recent years as part of implementing the Sustainable Development Goals. The fuel and energy complex (FEC) as such is the largest environment polluter, accounting for $48 \%$ of the hazardous substances polluted in the country's air, $27 \%$ of the polluted water sources, more than $30 \%$ of the solid production wastes and nearly $70 \%$ of the total volume of gases creating the greenhouse effect. But because the energy generated by FEC is delivered to other industries, each joule received by industries (productions) has an equivalent of hazardous pollutions depending on the technologies used. In fact, the energy efficiency indicators are environmental-economic indicators, because they reflect the ecological sustainability of a territory; they allow for assessing the change in the energy capacity resulting from the purposeful actions, the change resulting from other factors (climatic, geographical, structure change in the economy), for identifying the elements with the largest impact on the change in energy consumption in various sectors of the economy.

The indicators of energy efficiency (energy capacity) and ecological sustainability appeared as equal problems of the economy of development in the UN documents in 2000. The ecological sustainability is associated with the energy efficiency, i.e., the reduced energy capacity of national economies in “Millennium Development Goals". The Millennium Development Goals set target parameters of indicators such as energy capacity of GDP and $\mathrm{CO}_{2}$ pollutions. The processes involved in extraction of primary energy resources, their processing and consumption, with the accompanying losses and pollutions of $\mathrm{CO}_{2}$, are components of the resource utilization chain. The indicators of energy efficiency (energy capacity) and $\mathrm{CO}_{2}$ pollutions allow for the assessment of processes occurring in the resource utilization chain. At regional and national level, energy indicators allow for: exercising control over implementation of programs on energy efficiency and reduction of $\mathrm{CO}_{2}$ pollution; assessing implemented programs on energy efficiency; planning future actions, predicting change with consideration to the need for energy resources.

The global indicators of the World Bank include the most important groups of energy and ecological indicators. In the World Bank reports, all the indicators of energy efficiency are divided into direct and indirect ones. The direct indicators include: GDP per unit of energy use (constant 2011 PPP \$ per $\mathrm{kg}$ of oil equivalent); Electric power consumption (kWh per capita); Energy use ( $\mathrm{kg}$ of oil equivalent per capita); energy use ( $\mathrm{kg}$ of oil equivalent); Alternative and nuclear energy ( $\%$ of total energy use); Combustible renewables and waste ( $\%$ of total energy); Fossil fuel energy consumption (\% of total); Investment in energy with private participation (current USD); Value lost due to electrical outages (\% of sales for affected firms); Energy production (kt of oil equivalent). The indirect ones include: $\mathrm{CO}_{2}$ emissions (kt); $\mathrm{CO}_{2}$ emissions (metric tons per capita); Road sector energy consumption (\% of total energy consumption); Research and development expenditure (\% of GDP); Other greenhouse gas emissions, HFC, PFC and SF6 (thousand metric tons of $\mathrm{CO}_{2}$ equivalent); Methane emissions (kt of $\mathrm{CO}_{2}$ equivalent); Nitrous oxide emissions (thousand metric tons of $\mathrm{CO}_{2}$ equivalent); Industry (including construction), value added (\% of GDP); Access to electricity (\% of population).

At international level, the indicators under study lay the ground for cross-country comparisons, which is the critical element in the framework of international negotiations on climate change. 
The indicators of energy efficiency (energy capacity) have become important in "green" accounts at macrolevel. The most common ones are: energy capacity of GDP on energy resources consumption (energy resources consumption / GDP); energy efficiency (an indicator reverse to energy capacity); specific indicators of GDP efficiency (electric capacity, heat capacity, oil capacity, gas capacity etc.). Energy capacity on consumption is the most widespread indicator in the world.

The indicator of electric capacity, widely used in combination with the indicator of energy capacity, measures the consumption of fuel in energy generation at various categories of energy plants. This indicator is intended for comparisons of technologies used in the main fuel consuming industry.

\section{Conclusion}

As neither of the "green economy" development indicators has been widely accepted by now, at the current phase of the national and international statistics development, there is no need in extracting the green products sector from the national economy. Yet, the dynamic assessment of the national economy greening is important, as its enables to measure the change in the environmental impact of the new model of the economy, to analyze the factors and find out the most effective methods to reduce environmental pressures from economic activities. An advantage of this assessment is its feasibility on the basis of the available statistical data.

A single international standard for typology of economic activities related with production of ecological goods and services has not existed by now. This standard can be elaborated as part of the UN environmentaleconomic accounting system. Data about the output of ecological goods and services have been supplied by Eurostat for selected European countries, and data on the employment in main ecological industries have been provided by OECD.

Unfortunately, the existing classification of goods and services does not include information about the purpose of goods that are produced. The most probable method for selecting such information is a sample questioning of buyers, which is incapable to provide reliable data for analyses of green economics development and policy making.

Although energy indices and indicators are widely used in many international accounting systems, the selection of a universal set of indicators constitutes a difficult problem. We tried to break all the indicators by two main groups: direct and indirect ones. The direct indicators allow for the direct assessment of change in the intensity and efficiency of processes involved in energy use. The indirect indicators can measure energy use in indirect ways: by indicators measuring the environmental burden, by indicators measuring R\&D expenditures, number of cars per capita etc.

In view of the inclusion of energy factors, the most acceptable one in the "green" accounting practice seems to be the indicator of adjusted net savings (genuine savings), often used in assessment, as mentioned by various researchers. The indicator of genuine savings can be an economic proxy for the notion of system's sustainability because, apart from nature resources, it includes other components required to ensure a range of options for future generations, equal to the options of the living generation. Net adjusted savings are computed as the change of this cumulative wealth in a period of time, for example in a year.

It should be noted that the methodology for computation of the indicators used in the monitoring of the World Bank can be often changed. The main drawback of the indicator of genuine savings is a high probability of incorrect or even missing data. Adjustments for the environment's degradation and the drastically shrinking biodiversity are recorded as a mere formality. Emissions are confined to a limited range of polluting substances, of which the most important one is $\mathrm{CO} 2$ pollutions. Depletions of underground waters or fishing areas, degradations of soils and so on and so forth are not included in the computations. But for the items that are included a serious problem still remains to be lack of correct methods for estimation of prices. All the above gives evidence of the need for constructing a database on sustainable development.

However, in spite of the weak sides, the new environmental-economic indicators under study signal the excessive consumption of natural resources and the apparent insufficiency of reinvestments of incomes from exploitations of renewable natural resources in non-renewable ones. Further "greening" of the socio-economic advancement indicators constitutes a vital problem and remains in the agenda of global and national institutes of development.

To have the assessment of green economics development performed, all the countries need to coordinate their effort in implementing accounting system on the basis of the system proposed by the UN at international level, in using harmonized typologies of economic activities pertaining to the green industry and green jobs, in using comparable key indicators, which enables for the statistical assessment of green economics development in time and space. To be widely used by policy makers, mass media, business communities and broader public, the system of "green economics" development indicators of needs to be based on freely available data, to have clear specification and the elaborated methodology for data collection. 


\section{References:}

Bowen,A. (2012). “Green Growth”What Does it Mean? Retrieved from: http://www.lse.ac.uk/GranthamInstitute/ wp-content/uploads/2014/02/green-growth-environmental-scientist-dec12.pdf (accessed 4 January 2020).

Economic and Social Commission for Asia and the Pacific (2012). Green Growth and Green Economy. Retrieved from: https://www.unescap.org/our-work/environment-development/green-growth-green-economy/ about (accessed 6 January 2020).

European Environment Agency (2016). Green Economy: Europe's Environment -An Assessment of Assessments. Retrieved from: https://www.eea.europa.eu/publications/europes-environment-aoa (accessed 4 January 2020).

Eurostat (2018). Access to Data: Main Tables. Retrieved from: http://ec.europa.eu/eurostat/web/sdi/maintables (accessed 4 January 2020).

GGKP (2013). Moving towards a Common Approach on Green Growth Indicators. Retrieved from: http: / /www.oecd.org/greengrowth/GGKP\%20Moving\%20towards\%20a\%20Common\%20Approach\%20 on\%20Green\%20Growth\%20Indicators\%5B1\%5D.pdf (accessed 2 January 2020).

Kennet, M., \& Heinemann, V. (2006). Green Economics: Setting the Scene. Aims, Context, and Philosophical Underpinning of the Distinctive New Solutions Offered by Green Economics. International Journal of Green Economics, vol. 1, issue 1/2, pp. 68-102.

Milani, B. (2005), What Is Green Economics? Retrieved from: http://www.greeneconomics.net/what $2 \mathrm{f} . h \mathrm{tm}$ (accessed 4 January 2020).

OECD (2011). Towards Green Growth: Monitoring Progress - OECD Indicators. Retrieved from: http: / / www.oecd.org/greengrowth/ 48224574.pdf (accessed 8 January 2020).

OECD (2014). Green Growth Studies Green Growth Indicators 2014. Retrieved from: https://wedocs.unep.org/ bitstream/handle/20.500.11822/9434/-Green_Growth_Indicators-2014OECD_GreenGrowthIndicators 2014.pdf.pdf? sequence $=3$ \&isAllowed $=y$ (accessed 5 January 2020$)$.

OECD (2015). Green Growth Studies Green Growth Indicators 2014. Retrieved from: https://wedocs.unep.org/ bitstream/handle/20.500.11822/9434/-Green_Growth_Indicators-2014OECD_GreenGrowthIndicators 2014.pdf.pdf? sequence $=3 \&$ isAllowed $=y$ (accessed 5 January 2020$)$.

OECD (2016). Measuring the transformation of the economy: green growth indicators - Policy Perspectives 2016. Retrieved from: https://issuu.com/oecd.publishing/docs/policy_perspective_ggi_final_web (accessed 7 January 2020).

OECD (2017). Green Growth Indicators 2017. Retrieved from: http://www.oecd.org/env/green-growthindicators-2017-9789264268586-en.htm (accessed 8 January 2020).

OECD (2018). Green Growth and Sustainable Development. Retrieved from: http://www.oecd.org/greengrowth/ OECD (2018). What is Green Growth and How Can it Help Deliver Sustainable Development? Retrieved from: http://www.oecd.org/greengrowth/whatisgreengrowthandhowcanithelpdeliversustainabledevelopment.htm (accessed 9 January 2020).

Sustainable Development Knowledge Platform (2013). Green Growth. Retrieved from: https://sustainabledevelopment.un.org/index.php?menu=1447 (accessed 4 January 2020).

The Green Economics Institute (2018). Introduction to Green Economics - What we do and Why we do it. Retrieved from: http://www.greeneconomicsinstitute.com/about (accessed 7 January 2020).

The Sustainable Development Goals (2018). 17 Goals to Transforms Our World. Retrieved from: https://www.un.org/sustainabledevelopment/sustainable-development-goals/ (accessed 4 January 2020).

The World Bank (2012). Inclusive Green Growth. The Pathway to Sustainable Development. Retrieved from: http://siteresources.worldbank.org/EXTSDNET/Resources/Inclusive_Green_Growth_May_2012.pdf (accessed 6 January 2020).

The World Bank (2013). How Do You Measure Green Growth? World Bank \& Partners Are Working on Indicators. Retrieved from: http://www.worldbank.org/en/news/feature/2013/04/04/creating-global-greengrowth-indicators (accessed 4 January 2020).

The World Bank (2017). The Little Green Data Book 2017 (English). Retrieved from: http://documents. worldbank.org/curated/en/239271500275879803/The-little-green-data-book-2017 (accessed 10 January 2020). UNEP (2012). Green Economy 101. Retrieved from: http://www.greenup-unep.org/green-economy/what-isgreen-economy.htm?lng=en\#.Wze5AGAzbDd (accessed 12 January 2020).

UNEP (2014). A Guidane Manual For Green Economy Indicators. Retrieved from: http://www.un-page.org/ files/public/content-page/unep_indicators_ge_for_web.pdf (accessed 12 January 2020). 